\title{
Quality attributes and properties of surubim (Pseudoplatystoma spp.) meat
}

\section{Atributos de qualidade e propriedade da carne de surubins Pseudoplatystoma spp.}

\author{
Letícia Emiliani Fantini ${ }^{1 *}$; Jorge Antonio Ferreira de Lara²; \\ Ádina Cléia Botazzo Delbem³; Thiago Tetsuo Ushizima ${ }^{4}$; \\ Jayme Aparecido Povh ${ }^{1}$; Cristiane Meldau de Campos ${ }^{5}$
}

\begin{abstract}
The aim of this study was to evaluate the quality attributes and properties of fillets from surubins (Pseudoplatystoma spp.) reared in cages and fishponds. The design of the study was completely randomized, with two treatments (cage and fishpond) and 16 replicates each. The fillets from fishes reared in cage and fishpond had a mean total weight of $134.71 \pm 33.11 \mathrm{~g}$ and $151.56 \pm 18.56 \mathrm{~g}$, respectively. The following parameters were analyzed: $\mathrm{pH}$, water retention capacity (WRC), color ( $\mathrm{L}^{*}$ brightness), (a* red), (b* yellow), and shear force (SF). The data were subjected to analysis of variance and the means were compared by Tukey's and Mann-Whitney (nonparametric) tests. Statistically significant differences $(\mathrm{p}<0.05)$ were observed for WRC, SF, and $\mathrm{pH}$ variables. Only for color attributes $\left(\mathrm{L}^{*}\right),\left(\mathrm{a}^{*}\right)$, $\left(b^{*}\right)$, no statistically significant difference $(\mathrm{p}>0.05)$ was detected between the treatments. A lower $\mathrm{pH}$ $(6.17 \pm 0.23)$ was observed in fillets from surubins reared in cage. As this is close to the isoelectric point of myofibrillar proteins, it reduces their net charge and, consequently, their capacity to retain water. Lower WRC of fillets obtained from fishes reared in cage $(61.46 \pm 1.62 \%)$ implies loss of nutritional value through the exudate released which results in drier fillets and compromised tenderness. In fillets from cage production, SF $(1.06 \pm 0.22 \mathrm{kgf})$ was higher than those from fishpond, i.e., the higher the shear force, the lower the tenderness of the fillet. On the basis of the observation that fillets from fishes reared in fishponds were more tender, this study confirmed that the quality of surubin fillets is influenced by the production system.
\end{abstract}

Key words: Aquaculture, fillet, shear force, siluriforme, tenderness

\section{Resumo}

Objetivou-se avaliar os atributos de qualidade e propriedades da carne de surubins Pseudoplatystoma spp. produzidos em tanque-rede e viveiro. Adotou-se o delineamento inteiramente casualizado, com dois tratamentos (tanque-rede e viveiro) e 16 repetições cada. Os filés, produzidos em tanque-rede

\footnotetext{
1 Discentes e Pesquisadores, Programa de Pós-Graduação em Ciência Animal, Faculdade de Medicina Veterinária e Zootecnia, Universidade Federal de Mato Grosso do Sul, UFMS, Campo Grande, MS, Brasil. E-mail: leticia.emiliani@hotmail.com; jayme. povh@ufms.br

2 Pesquisador, Empresa Brasileira de Pesquisa Agropecuária, Corumbá, MS, Brasil. E-mail: jorge.lara@embrapa.br

3 Pesquisadora, Bolsista de Desenvolvimento Científico Regional CNPq/Fundect, Corumbá, MS, Brasil. E-mail: adelbem@yahoo. com.br

4 Pesquisador, Empresa Mar \&Terra Indústria e Comércio de Pescado Ltda, Itaporã, MS, Brasil. E-mail: thiago@mareterra.com. br

5 Profa, Programa de Pós-Graduação em Zootecnia, Universidade Estadual de Mato Grosso do Sul, UEMS, Aquidauana, MS, Brasil. E-mail: cmeldau@uems.br

* Author for correspondence
} 
e viveiro, respectivamente, apresentavam peso total médio de $134,71 \pm 33,11 \mathrm{~g}$ e $151,56 \pm 18,56 \mathrm{~g}$. Os parâmetros analisados foram: $\mathrm{pH}$, capacidade de retenção de água (CRA), cor ( $\mathrm{L}^{*}$ luminosidade), ( $\mathrm{a}^{*}$ vermelho), ( $\mathrm{b}^{*}$ amarelo) e força de cisalhamento (FC). Os dados foram submetidos à análise de variância e as médias comparadas pelo teste de Tukey e Mann-Whitney (não paramétrico). Foram verificadas diferença estatística $(\mathrm{p}<0,05)$ para as variáveis CRA, FC e pH. Apenas para a variável cor $\left(\mathrm{L}^{*}\right),\left(\mathrm{a}^{*}\right),\left(\mathrm{b}^{*}\right)$ não foi verificado diferença estatística $(\mathrm{p}>0,05)$ entre os tratamentos. Filés de surubins produzidos em tanque-rede apresentaram menor $\mathrm{pH}(6,17 \pm 0,23)$, que, se aproxima do ponto isoelétrico das proteínas miofibrilares, reduzindo a sua carga líquida e, consequentemente, sua capacidade de reter água. A menor CRA da carne nos peixes produzidos em taque-rede $(61,46 \pm 1,62 \%)$ implica perdas do valor nutritivo pelo exudato liberado, resultando em carne mais seca e com maciez comprometida. $\mathrm{O}$ resultado de $\mathrm{FC}$ da produção em tanque-rede $(1,06 \pm 0,22 \mathrm{kgf})$ foi maior em relação a produção em viveiro e, quanto maior a força dispensada menor é a maciez apresentada pelo corte de carne. A qualidade da carne de surubins é influenciada pelo sistema de criação. Os peixes produzidos em viveiros apresentaram carne mais macia.

Palavras-chave: Aquicultura, filé, força de cisalhamento, maciez, siluriforme

\section{Introduction}

The quality of fish meat relies on a number of factors, such as the season of the year, age, place of capture, handling, transport, processing, and production system. In fish farming, it is important to choose the most appropriate production system according to the goals, production species, and target market (CREPALDI et al., 2006).

Fish farming in ponds is one of the oldest methods in aquaculture, mainly used in extensive and semiintensive production systems and, according to Honorato et al. (2014), is an excellent alternative for the rational use of water bodies that present difficulties for practicing conventional fish farming. This allows the use of plankton production (SCORVO FILHO et al., 2004), which could improve feed conversion in several fish species (which have gill rakers) and influence oxygen production, interfering with the dynamics of water parameters.

Farming fish in cages allows using higher stocking densities when compared to fishponds. For spotted surubim Pseudoplatystoma corruscans, Scorvo Filho et al. (2008) used stocking densities of 0.75 fishes $/ \mathrm{m}^{2}$ for fishpond farming and of 67 fishes $/ \mathrm{m}^{3}$ and 133 fishes $/ \mathrm{m}^{3}$ for cage farming, while Liranço et al. (2011) used densities of 0.25 fishes/ $\mathrm{m}^{2}$ for fishpond farming and 22.2 fishes $/ \mathrm{m}^{3}$ for cage farming. Although studies show that cage fish farming is economically advantageous (LIRANÇO et al., 2011), the fishpond production method can provide desirable characteristics in the final product quality.

Although surubins have not been genetically improved, the yield obtained is high (FANTINI et al., 2013). Oliveira et al. (2014) compared the performance of cachara Pseudoplatystoma reticulatum, and its hybrid (Pseudoplatystoma spp.) and observed lower standardization of the morphometric characteristics, however, the group performed better.

Burkert et al. (2008) reported 47.79\% fillet yield for surubins reared in cages, whereas Fantini et al. (2013) obtained values of $40.16 \%$ and $38.97 \%$ for surubins reared in cages and fishponds, respectively. Fantini et al. (2014) reported that surubins produced in fishponds under different stocking densities had average fillet yields of $42.75 \pm 3.43 \%$.

Surubins have become popular with consumers and are used in common dishes such as fillets, steaks, appetizers, and more refined dishes like carpaccio. However, the lack of product standardization of surubim fillets may cause uncertainty among consumers; the products may either be of good quality or with unpleasant flavors. Due to the lack of information about the characteristics of surubins meat, this study aimed to assess the quality attributes and properties of fillets obtained from surubins reared in cages and fishponds. 


\section{Materials and Methods}

Hybrid surubins, without sex distinction and with an initial mean weight of $20 \mathrm{~g}$ were reared in a commercial fish farm, in a cage of $2 \times 2 \times 1,2 \mathrm{~m}$, totaling useful volume of $4 \mathrm{~m}^{3}\left(70\right.$ fishes $\left./ \mathrm{m}^{3}\right)$ and in a fishpond de 20x50 m, totaling $1,000 \mathrm{~m}^{2}$ with a depth of $1.20 \mathrm{~m}$ (10 fishes $\left./ \mathrm{m}^{2}\right)$. The experimental design was completely randomized, with two treatments, corresponding to cage and fishpond production systems and sixteen replicates each, for which each fish was considered an experimental unit.

The fish of both production systems were fed with extruded feed for carnivorous fish according to the following production steps: 1) fish weighing up to $100 \mathrm{~g}$ were fed with 2 to $4 \mathrm{~mm}$ diameter pellets containing 40\% crude protein - CP $(11.0 \%$ Ethereal Extract - EE, 2.5\% crude fiber - CF, 14.0\% Mineral Matter-MM, 3.5\% calcium and $2.0 \%$ phosphorus); 2) Fish between 100 and $300 \mathrm{~g}$ were fed 4 to $5 \mathrm{~mm}$ pellets with $38 \% \mathrm{CP}(11.5 \% \mathrm{EE}, 3.0 \% \mathrm{CF}, 13.0 \%$ MM, 2.5/3.5\% calcium and 2.0\% phosphorus); 3 ) Fish between 300 and $500 \mathrm{~g}$ were fed with 6 to 8 $\mathrm{mm}$ pellets containing $36 \%$ crude protein $(11.0 \%$ EE, 3.5\% CF, $12.0 \% \mathrm{MM}, 2.5 / 3.0 \%$ calcium and $1.8 \%$ phosphorus); and, 4) Fish over $500 \mathrm{~g}$ were fed 12 to $15 \mathrm{~mm}$ pellets with $38 \% \mathrm{CP}(8.0 \% \mathrm{EE}$, $3.2 \% \mathrm{CF}, 12.5 \% \mathrm{MM}, 3.0 / 3.8 \%$ calcium and $2.0 \%$ phosphorus).

The amount of food offered was based on the biomass, being $8 \%$ in the first phase distributed over four times daily; $5 \%$ in the second phase, distributed twice daily, and $2 \%$ in the last two phases, twice daily. After a 12-month production cycle, surubins were fasted for $48 \mathrm{~h}$ to empty their gastrointestinal system. Sixteen fishes were sampled from each treatment, with a mean total weight of $867 \pm 205$ $\mathrm{g}$ and $933 \pm 106 \mathrm{~g}$ for cage and fishpond farming, respectively. A total of 32 fishes were sacrificed by thermal shock on ice.

Using a knife, fillets were cut from surubins by a single person. To obtain lateral fillets, dorsolateral muscles were cut lengthwise, along the entire spine, from the cranial region to the end of the caudal peduncle. From the back and towards the belly of the animal, the skin was removed, as suggested by Burkert et al. (2008). Skinless fillets of fishes from cage and fishpond farming, with a mean total weight of $134.71 \pm 33.11 \mathrm{~g}$ and $151.56 \pm 18.56$ $\mathrm{g}$, respectively, were frozen and transported to the Laboratory for Meat Analysis of the Brazilian Enterprise for Agricultural Research - EMBRAPA, Center of Agricultural Research of the Pantanal CPAP, research unit of Corumbá - MS, to evaluate the quality of the meat.

To assess quality attributes and properties of surubim meat, the following parameters of lateral (located in the lateral region of the fish body) skinless fillets were characterized: $\mathrm{pH}$, water retention capacity (WRC), color $\left(\mathrm{L}^{*}, \mathrm{a}^{*}, \mathrm{~b}^{*}\right)$, and shear force (SF). The samples were taken from the fillets representing three points for each variable.

For the analysis, fillet samples were thawed at a temperature of $7{ }^{\circ} \mathrm{C}$ in the refrigerator for about 12 hours. Deep intramuscular $\mathrm{pH}$ was determined before performing other tests and this value was read in a Mettler Toledo $\mathrm{pH}$ meter using a specific electrode for meats (model 1140). Color and values of L*, a*, and b* (Hunter system, brightness and red and yellow color pattern, respectively) of the fillets were assessed using a Minolta CR-10 colorimeter.

Water retention capacity (WRC) was evaluated using the methodology described by Nakamura and Katoh (1985). One gram of natural muscle was weighed using a BEL analytical scale in a microtube containing filter paper. The sample (triplicated) was centrifuged in a 5417R Eppendorf centrifuge at $1500 \times \mathrm{g}$, for $4 \mathrm{~min}$ at $4{ }^{\circ} \mathrm{C}$, and weighed before drying in an oven, at $60{ }^{\circ} \mathrm{C}$ for $12 \mathrm{~h}$. Then, samples were weighed again for the following calculation:

$\mathrm{WRC}=(\mathrm{WSAC}-\mathrm{WSW} / \mathrm{WIS}) \times 100$

WSAC $=$ weight of the sample after centrifugation

WSW= weight of the dried sample

WIS $=$ weight of the initial sample 
Shear force (SF) was evaluated by cooking whole fillet samples at $90{ }^{\circ} \mathrm{C}$ in a water bath, until the internal temperature reached $72{ }^{\circ} \mathrm{C}$ (about $15 \mathrm{~min}$ ). After this procedure, fillet samples were maintained at $5{ }^{\circ} \mathrm{C}$. Shear force (SF) was calculated using a texturometer (TAXT2 model) with a specific blade for shear force, which was previously calibrated with a standard weight of $2 \mathrm{~kg}$. With the aid of a rectangular support, the fillets were compressed axially until complete cut of the sample, which were put on texturometer and cut to calculate shear force. The Texture Expert Exceed program, version 2.5, was used to collect the data and calculate the texture (expressed in $\mathrm{kgf}$ ).

The data were submitted to analysis of variance and Tukey's test, establishing a level of significance of $5 \%$. The data were tested for normality and those data points that did not follow a normal distribution were analyzed by the non-parametric MannWhitney test, using the statistical program SAS, version 9.1 .

\section{Results and Discussion}

The quality of fillets of surubim is influenced by the production system. The means values for the variables analyzed ( $\mathrm{pH}, \mathrm{WRC}$, color and SF) are described in Table 1. Fillets obtained from surubins reared in cage had a lower $\mathrm{pH}$ than those from fishpond farming. This can be justified by the explanation of Ordoñez (2007) and Ruiz (2007) where claim that at low $\mathrm{pH}$, the myofibril structure retains less water because the $\mathrm{pH}$ approaches the isoelectric point of myofibrillar proteins, resulting in a reduced net charge, and consequently, diminished ability to retain water. The stocking density used in cage production systems, which could have stressed the fishes and decreased the $\mathrm{pH}$, might have caused the difference in $\mathrm{pH}$. Despite the differences observed, the $\mathrm{pH}$ values are within the range recommended by article 443 of the Regulation of Industrial and Sanitary Inspection of Products of Animal Origin (RIISPOA), where $\mathrm{pH}$ values below 6.5 are acceptable (BRASIL, 1997).

Table 1. Mean values \pm standard deviation of $\mathrm{pH}$, water retention capacity (WRC), color $\left(\mathrm{L}^{*}, \mathrm{a}^{*}, \mathrm{~b}^{*}\right)$, and shear force (SF) of fillets from surubins (Pseudoplatystoma spp.) reared in cages (Treatment 1) and fishponds (Treatment 2).

\begin{tabular}{ccc}
\hline \multirow{2}{*}{ Variables } & \multicolumn{3}{c}{ Treatments } \\
\cline { 2 - 3 } & Cages & Fishponds \\
\hline $\mathrm{pH}$ & $6.17 \pm 0.23^{\mathrm{b}}$ & $6.39 \pm 0.10^{\mathrm{a}}$ \\
WRC $(\%)$ & $61.46 \pm 1.62^{\mathrm{b}}$ & $63.59 \pm 2.12^{\mathrm{a}}$ \\
$\mathrm{L}^{*}$ & $48.73 \pm 3.10^{\mathrm{x}}$ & $49.09 \pm 2.16^{\mathrm{x}}$ \\
$\mathrm{a}^{*}$ & $1.50 \pm 1.15^{\mathrm{x}}$ & $2.36 \pm 1.62^{\mathrm{x}}$ \\
$\mathrm{b}^{*}$ & $9.60 \pm 1.25^{\mathrm{x}}$ & $10.03 \pm 1.56^{\mathrm{x}}$ \\
SF $(\mathrm{kgf})$ & $1.06 \pm 0.22^{\mathrm{a}}$ & $0.78 \pm 0.17^{\mathrm{b}}$ \\
\hline
\end{tabular}

Different letters in the same row indicate significant differences between treatments $(\mathrm{p}<0.05$, Tukey's test).

Lower WRC of fillets from fishes reared in cages implies loss of nutritional value due to the exudate released, which results in drier meat and compromised tenderness (MORENO et al., 2008). In this process, protein denaturation occurs (GOÑI; SALVADORI, 2010) while the opposite is observed with meats with higher water holding capacity (PINHEIRO et al., 2010) as observed in fish production in ponds.
Water retention capacity of fishes obtained in the present study was higher than that obtained by Lara et al. (2010), who investigated fillets of spotted surubim Pseudoplatystoma corruscans from the Paraguay River (Corumbá-MS), with the value of WRC estimated as $58.97 \pm 3.24 \%$. In that case, besides the difference in the age of the fishes, the authors above worked with a pure species (spotted 
surubim), whereas in this study, we used a cross between the spotted surubim and cachara.

The $\mathrm{L}^{*} \mathrm{a}^{*} \mathrm{~b}^{*}$ space, also known as CIELAB, is a color measurement system widely used in various areas. In this space, $\mathrm{L}^{*}$ indicates lightness $\left(\mathrm{L}^{*} 0=\right.$ black, $100=$ white $)$ and $\mathrm{a}^{*}$, chromaticity coordinates, where the $-\mathrm{a}^{*}+\mathrm{a}^{*}$ axis varies from green to red and the $-\mathrm{b}^{*}+\mathrm{b} *$ axis, from blue to yellow (MACDOUGALL, 1994).

Factors such as production conditions (HALLIER et al., 2007), different biological conditions, diet (ERIKSON; MISIMI, 2008), storage and management can affect brightness ( $\left.\mathrm{L}^{*}\right)$ and change the color of the product. However, no changes were observed in this study.

According to Sarnimento (2006), higher values of brightness $\left(\mathrm{L}^{*}\right)$ are indicative of a lighter fillet color, usually desired by consumers since darkening of meat is commonly associated with deterioration. The color values $\left(\mathrm{L}^{*}\right)$ obtained in this study are lower than those in other meats; therefore, fish is also referred to as white meat. Medeiros et al. (2012) obtained L* values varying between 49.59 and 53.47 in poultry meat, whereas Watanabe et al. (2012) obtained values between 46.47 and 50.82 in pigs.

Cage and fishpond farming did not influence the values of variables $a^{*}$ and $b^{*}$. In fishes $(p>0.05)$, values of $a^{*}$ may be considered lower when compared to other meats, such as cattle and sheep, probably because variable a* indicates the intensity of red color and is related to the content of myoglobin in muscles (MAIA; OGAWA, 1999). Therefore, the higher the $a^{*}$ value, the more red is the meat. Possibly, the reverse occurs with variable $b^{*}$, yellow color pattern, since higher values were obtained from fish fillets when compared to other meats.

The results of SF in cage production were higher when compared to fishpond farming $(p<0.05)$. According to Alves and Mancio (2007), the higher the force dispensed, the lower the tenderness of the fillets, which reflects higher tenderness of fillets obtained from fishes reared in ponds.

The age of the animals is an important factor in the analysis of shear force, because aging increases the number of muscle thermostable collagen crosslinks, which favor the hardness of the meat. Studies on other animal species have reported higher shear force. Medeiros et al. (2012) observed a shear force of $3.19 \mathrm{kgf}$ in breast fillet of Cobb 700 broiler chicken slaughtered at 42 days. Agostini et al. (2011) evaluated the effects of ractopamine supplementation $(0,10$, and $20 \mathrm{ppm})$ in the diets of male castrated pigs and finishing-females and its influence on meat quality. The authors did not observe difference $(p>0.05)$ in shear force and the mean values varied between $5.28 \pm 0.66$ and 5.50 $\pm 0.89 \mathrm{kgf}$.

Furlan (2013) investigated the quality and economical value enhancement of Atlantic seabob prawns and reported mean shear force values of $0.67 \pm 0.1 \mathrm{kgf}$. Of the discussed meats, prawn meat stands out in terms of tenderness, followed by fish fillet. Pork and poultry meats distanced themselves from meat that originated from aquaculture in terms of softness. This feature is just one of the positive aspects that can be highlighted in the advertising and marketing of fish meat, which can result in increased consumption.

Surubins reared in different production systems can be easily found on supermarket shelves. However, under the experimental conditions used in this study, we observed higher water retention, and therefore, more succulent and tender fillets from fish reared in ponds.

\section{Conclusions}

The quality of surubim (Pseudoplatystoma spp.) fillets is influenced by the production system. The fishes reared in pond have a more tender meat. 


\section{Acknowledgments}

The authors would like to thank Mrs. Olivia Aparecida Soares Fantini for her support throughout this study.

\section{References}

AGOSTINI, P. S.; SILVA, C. A.; BRIDI, A. M.; ABRAMI, R. A. M.; PACHECO, G. D.; LOZANO, A. P.; YWAZAKI, M. S.; DALTO, D. B.; GAVIOLI, D. F.; OLIVEIRA, E. R.; BONAFÉ, E. G.; SOUZA, N. E.; VISENTAINER, J. V. Efeito da ractopamina na performance e na fisiologia do suíno. Archivos de Zootecnia, Córdoba, v. 60, n. 231, p. 659-670, 2011.

ALVES, D. D.; MANCIO, A. B. Maciez da carne bovina - uma revisão. Revista da Faculdade de Zootecnia, Veterinária e Agronomia, Uruguaiana, v. 14, n. 1, p. 193216. 2007.

BRASIL. Ministério da Agricultura, Pecuária e Abastecimento. Departamento Nacional de Inspeção de Produtos de Origem Animal - DIPOA, Divisão de normas técnicas. Regulamento de inspeção industrial e sanitária de produtos de origem animal - RIISPOA. Aprovado pelo decreto n. 30691 de 29/03/52, alterado pelos Decretos $n^{0} \mathrm{~s} 1.255$ de 25-06-62, 1.236 de 02-0994, n $\mathrm{n}^{\circ} 1.812$ de 08-02-96 e no 2.244 de 04-06-97. Brasília, 1997. Capítulo VII - Pescados e derivados, Seção 1 Pescado, 116 p.

BURKERT, D.; ANDRADE, D. R.; SIROL, R. N; SALARO, A. L.; RASGUIDO, J. E. A.; QUIRINO, C. R. Rendimentos do processamento e composição química de filés de surubim cultivado em tanques-rede. Revista Brasileira de Zootecnia, Viçosa, MG, v. 37, n. 7, p. 1137 1143, 2008.

CREPALDI, D. V.; TEIXEIRA, E. A.; FARIA, P. M. C.; RIBEIRO, L.P.; MELO, D. C.; CARVALHO, D.; SOUSA, A. B.; SATURNINO, H. M. Sistemas de produção na piscicultura. Revista Brasileira de Reprodução Animal, Belo Horizonte, v. 30, n. 3/4, p. 86-99, 2006.

ERIKSON, U.; MISIMI, E. Atlantic salmon skin and fillet color changes effected by perimortem handling stress, rigor mortis, and ice storage. Journal of Food Science: Food Chemistry, Chicago, v. 73, n. 2, p. 50-59, 2008.

FANTINI, L. E.; OLIVEIRA, C. A. L.; RODRIGUES, R. A.; ZARDIN, A. M. S. O.; USHIZIMA, T. T.; CAMPOS, C. M. Rendimento de carcaça de surubins
Pseudoplatystoma spp. produzidos em viveiros sob diferentes densidades de estocagem. Semina: Ciências Agrárias, Londrina, v. 35, n. 5, p. 2769-2780, 2014.

FANTINI, L. E.; RODRIGUES, R. A.; NUNES, A. L.; SANCHEZ, M. S.; USHIZIMA, T. T.; CAMPOS, C. M. Rendimento de carcaça de surubins Pseudoplatystoma spp. produzidos em tanque-rede e viveiro. Revista Brasileira de Saúde Produção Animal, Salvador, v. 14, n. 3, p. 538-545, 2013.

FURLAN, E. F. Qualidade e valorização do camarão sete-barbas (Xiphopenaeus Kroyer, Heller, 1862): aspectos sensoriais e vida útil em gelo. 2013. Tese de Doutorado (Doutorado em Ciências) - Faculdade de Saúde Pública da Universidade de São Paulo, São Paulo.

GOÑI, S. M.; SALVADORI, V. O. Prediction of cooking times and weight losses during meat roasting. Journal of Food Engineering, Essex, v. 100, p. 1-11, 2010.

HALLIER, A.; CHEVALLIER, S.; SEROT, T.; PROST, C. Influence of farming conditions on colour and texture of European catfish (Silurus glanis) flesh, Journal of the Science of Food and Agriculture, London, v. 87, n. 5, p. 814-823, 2007.

HONORATO, C. A.; USHIZIMA, T. T.; QUINTANA, C. I. F.; CAMPOS, C. M.; MARCONDES, V. M.; NASCIMENTO, C. A.; SANTAMARIA, F. M. Níveis de proteína digestível para surubim (Pseudoplatystoma sp.) criados em tanque-rede. Semina: Ciências Agrárias, Londrina, v. 35, n. 5, p. 2781-2792, 2014.

LARA, J. A. F.; GARBELINI, J. S.; DELBEM, A. C. B. Determinação da capacidade de retenção de água em filés de pintado obtidos no rio Paraguai (Corumbá-MS). In: SIMPÓSIO SOBRE RECURSOS NATURAIS E SOCIOECONÔMICO DO PANTANAL, SIMPAM, 5., 2010, Corumbá. Anais... Corumbá: SIMPAM, 2010. CDROM.

LIRANÇO, A. D. S.; ROMAGOSA, E.; SCORVOFILHO,J.D. Desempenho produtivode Pseudoplatystoma corruscans estocados em sistemas de criação: semiintensivo (viveiro escavado) e intensivo (tanque-rede). Ciência Rural, Santa Maria, v. 41, n. 3, p. 524-530, 2011.

MACDOUGALL, D. B. Colour meat- its basis and importance. In: PEARSON, A. M.; DUTSON. T. R. (Ed.). Quality atributes and their measurement in meat, poutry and fish product. London: Black Academic, 1994. Chap. 9, p. 34-78. (Advances in meat research series, 9).

MAIA, E. L.; OGAWA. M. Cor. In: OGAWA, M.; MAIA, E. L. (Org.). Manual de pesca - ciência e tecnologia do pescado. São Paulo: Livraria Varela Ltda., 1999. cap. 5, p. 75-85. 
MEDEIROS, L. G.; OBA, A.; SHIMOKOMAKI, M.; PINHEIRO, J. W.; SILVA, C. A.; SOARES, A. L.; PISSINATI, A.; ALMEIDA, M. Desempenho, características de carcaça e qualidade de carne de frangos de corte suplementados com selênio orgânico, Semina: Ciências Agrárias, Londrina, v. 33, p. 3361-3370, 2012. Suplemento 2.

MORENO, G. M. B.; LOUREIRO, C. M. B.; SOUZA, H. B. A. Características qualitativas da carne ovina. Revista Nacional da Carne, São Paulo, n. 381, p. 76-90, 2008.

NAKAMURA, M.; KATOH, K. Influence of thawing method on several properties of rabbit meat. Bulletin of Ishikawa Prefecture College of Agriculture, Ishikawa, v. 11, p. 45-49, 1985.

ORDOÑEZ, J. A. Tecnologia de alimentos. Porto Alegre: Artmed, 2007. v. 2, 172 p.

OLIVEIRA, A. M. S.; OLIVEIRA, C. A. L.; RODRIGUES, R. A.; SANCHEZ, M. S. S.; NUNES, A. L.; FANTINI, L. E.; CAMPOS, C. M. Crescimento de juvenis de Pseudoplatystoma reticulatum e Pseudoplatystoma spp. em viveiro. Semina: Ciências Agrárias, Londrina, v. 35, n. 2, p. 1091-1098, 2014.

PINHEIRO, R. S. B; JORGE, A. M.; SOUZA, H. B. A.; BOIAGO, M. M. Coloração da gordura e qualidade da carne de ovelhas de descarte abatidas em distintos estágios fisiológicos. Arquivo Brasileiro de Medicina Veterinária e Zootecnia, Belo Horizonte, v. 62, n. 2, p. 468-474, 2010.

RUIZ, J. Ingredients. In: TOLDRA, F. (Ed.). Handbook of fermented meat and poultry. Iowa: Blackwell, 2007. p. 51-76.
SARNIMENTO, A. M. L. Características microbiolóligas, físico-química e sensoriais de filés de tilápias (Oreochromis niloticus) conservados em atmosferas modificadas sob refrigeração. 2006. Dissertação (Mestrado em Ciencia e Tecnologia de Alimentos) - Universidade Federal de Viçosa, Viçosa, MG.

SCORVO FILHO, J. D.; ROMAGOSA, E.; AYROZA, L. M. S. FRASCÁ-SCORVO, C.M.D. Desempenho do pintado, Pseudoplatystoma corruscans (Spix \& Agassiz, 1829) criado nos sistemas intensivo e semi-intensivo. In: CONGRESSO DA AQUABIO AQUIMERCO, 2004, Vitória. Anais... Vitória: Aquaciência, 2004. p. 145.

SCORVO FILHO, J. D.; ROMAGOSA, E.; AYROZA, L. M. S.; FRASCÁ-SCORVO, C. M. D. Desempenho produtivo do pintado, Pseudoplatystoma corruscans (Spix \& Agassiz, 1829), submetidos a diferentes densidades de estocagem em dois sistemas de criação: intensivo e semi-intensivo. Boletim do Instituto de Pesca, São Paulo, v. 34, n. 2, p. 181-188, 2008.

WATANABE, P. H.; THOMAZ, M. C.; PASCOAL, L. A. F.; RUIZ, U. S.; DANIEL, E.; AMORIM, A. B.; CRISTANI, J.; CASTRO, F. F. Qualidade da carne de fêmeas suínas alimentadas com diferentes concentrações de ractopamina na dieta. Arquivo Brasileiro de Medicina Veterinária e Zootecnia, Belo Horizonte, v. 64, n. 5, p. 1381-1388, 2012. 
